\title{
Urethral Cancer Pathologic Primary Tumor TNM Finding v7
}

National Cancer Institute

\section{Source}

National Cancer Institute. Urethral Cancer Pathologic Primary Tumor TNM Finding v7. NCl Thesaurus. Code C89369.

A pathologic finding about one or more characteristics of urethral cancer, following the rules of the TNM AJCC V7 classification system as they pertain to staging of the primary tumor. 